\title{
Urban Living Labs: Towards an Integrated Understanding of their Key Components
}

\author{
Diana Chronéer, Anna Ståhlbröst, and Abdolrasoul Habibipour
}

\author{
" Living in cities is an art, and we need the vocabulary of art, of ") \\ style, to describe the peculiar relationship between man and \\ material that exists in the continual creative play of urban \\ living. The city as we imagine it, then, soft city of illusion, myth, \\ aspiration, and nightmare, is as real, maybe more real, than the \\ hard city one can locate on maps in statistics, in monographs \\ on urban sociology and demography and architecture.
}

Jonathan Raban

Travel writer, critic, and novelist

\begin{abstract}
In today's ongoing urbanization and escalating climate change, there is an increasing demand on cities to be innovative and inclusive to handle these emerging issues. As an answer to these challenges, and in order to generate and adopt sustainable innovations and naturebased solutions in the urban areas, the concept of urban living labs has emerged. However, to date, there is confusion concerning the concept of the urban living lab and its key components. Some interpret the urban living lab as an approach, others as a single project, and some as a specific place - and some just do not know. In order to unravel this complexity and better understand this concept, we sought to identify the key components of an urban living lab by discussing the perspective of city representatives in the context of an urban living lab project. To achieve this goal, we reviewed previous literature on this topic and carried out two workshops with city representatives, followed by an open-ended questionnaire. In this article, we identify and discuss seven key components of an urban living lab: governance and management structure; financing models; urban context; nature-based solutions; partners and users (including citizens); approach; and ICT and infrastructure. We also offer an empirically derived definition of the urban living lab concept.
\end{abstract}

\section{Introduction}

Nowadays, cities are facing increasing urban complexity and grand societal challenges. Hence, there is a growing trend to make urban areas more adaptable to the needs of their citizens by preventing social problems as well as viewing the cities as a vehicle for innovation in urban planning processes (Juujärvi \& Pesso, 2013; Scholl \& Kemp, 2016). To meet these challenges, decision makers and other relevant stakeholders aim to develop the city as a laboratory to generate innovative solutions (Juujärvi \& Pesso, 2013); an approach that is in line with the living lab concept.

Living labs are generally known as a way to manage innovation processes in an open, inclusive, and collaborative approach in which the innovations are developed by engaging various stakeholders including public or- ganizations, private sectors, universities, and citizens (Bergvall-Kåreborn et al., 2009; Ståhlbröst, 2008). So, it is important to include external sources of knowledge and ideas within the innovation process, which is consistent with the notion of "open innovation", a term that was first coined by Chesbrough (2003) and is at the core of the living lab concept. Also, living labs are based on specific methodologies and tools, and they are implemented through specific innovation projects and community-building activities (Schaffers \& Turkama, 2012). But, despite attempts in the literature to clarify the concept (e.g., Almirall et al., 2012; Leminen, 2015), living lab practices and theories are still under-researched (Schuurman, 2015).

As cities becomes an arena for innovation, the need grows for new approaches for citizen engagement, urban development, and new collaboration models (Evans 


\section{Urban Living Labs: Towards an Integrated Understanding of their Key Components}

Diana Chronéer, Anna Ståhlbröst, and Abdolrasoul Habibipour

\& Karvonen, 2011). As an answer to this growing need, the concept of the urban living lab has emerged. In the urban living lab, the whole city is viewed as a living laboratory where citizens and other stakeholders are actively involved in the process of designing, developing, implementing, testing, and evaluating an innovation (Veeckman \& van der Graaf, 2015). Accordingly, the aim of an urban living lab is to generate and adopt sustainable innovations and solutions in the urban system in light of the urban sustainability transition (Steen \& van Bueren, 2017). Despite this, there are few studies about the concept of the urban living lab (Baccarne, Mechant, Schuurman, Colpaert, \& De Marez, 2014; Steen \& van Bueren, 2017) and, as previous studies show (Steen \& van Bueren, 2017; Voytenko et al., 2016), there is no general scientific agreement on what an urban living lab is and what constitutes the required components of an urban living lab. One plausible explanation for this is that most of the studies that have presented a definition, a framework, or a model for an urban living lab without focusing on its main characteristics. As a result, the concept becomes a mixture of components, activities, aims, principles, and actions that should be considered in an urban living lab (e.g., Juujärvi \& Pesso, 2013; Scholl \& Kemp, 2016; Steen \& van Bueren, 2017). This, in turn, leads to greater complexity and vagueness around the urban living lab concept. Therefore, we argue that the literature requires a comprehensive clarification of the concept if we are to understand and study the effects of an urban living lab and gain benefits from its implementation in cities around the globe. As a first step towards this clarification, we need to identify what constitutes an urban living lab, what are its key components, and how we can understand them.

Considering the key components of a "generic" or "traditional" living lab, five of them are well-known: 1) ICT and infrastructure; 2) management; 3) partners and users; 4) research; and 5) approach (Bergvall-Kåreborn et al., 2009; Ståhlbröst, 2008). However, given the early stages of the development of urban living labs (Bulkeley et al., 2016), and despite the fact that some studies have presented different elements, characteristics, and features of an urban living lab (Steen \& van Bueren, 2017; Voytenko et al., 2016), to our knowledge, there are still no studies exploring the five key components of a traditional living lab as outlined by Bergvall-Kåreborn and colleagues (2009) and Ståhlbröst (2008) when it comes to the urban context. Therefore, this article explores the differences (if any) between the traditional living lab key components and those in an urban context. In contrast to more "traditional" living lab approaches, urban living labs have a complexity built into them consisting of aspects such as politics, power of decision making, financing models, etc., which remains unaccounted for. Moreover, several questions remain unanswered, such as: What is the main objective of an urban living lab? What challenges does it aim to solve? What governance model is suitable for an urban living lab? What approaches should be adopted in an urban living lab? Who should be engaged in the innovation process and how?

Hence, in this study, we aim to define and discuss the key components of an urban living lab, which will further our understanding of the concept. The research has been carried out in an EU funded project called UnaLab (No. 730052-2), which incorporates ten different cities in Europe aiming to implement urban living labs to support the development of nature-based solutions in cities. The International Union for Conservation of Nature (IUCN) defines nature-based solutions as: “... actions to protect, sustainably manage and restore natural or modified ecosystems, which address societal challenges (e.g., climate change, food and water security or natural disasters) effectively and adaptively, while simultaneously providing human well-being and biodiversity benefits" (see Frantzeskaki et al., 2017). To support our research, it is important to understand how previous studies have grappled with the concept of an urban living lab; to include the perspective of cities and how they have interpreted the key components; as well to move forward our understanding of the concept of the urban living lab as a whole. In so doing, we first review previous literature on this topic and then present the results of two workshops with the city representatives, followed by an open-ended questionnaire.

The remainder of this article is structured as follows: the next section presents a literature review on the topic, which is followed by the overall methodology of the study. After that, the results of the two workshops as well as the questionnaire are presented. Then, we discuss the findings and offer some concluding remarks.

\section{Literature Review}

When looking at the concept of living labs, we can discern that there is a growing trend to involve citizens (and other stakeholders) in different city development projects with the aim to create urban areas that are 


\section{Urban Living Labs: Towards an Integrated Understanding of their Key Components}

Diana Chronéer, Anna Ståhlbröst, and Abdolrasoul Habibipour

more adaptable to different citizens' needs (cf. Baccarne, Mechant, Schuurman, Colpaert, \& De Marez, 2014). Today, urban areas are seen by different stakeholders (e.g., city planners, universities, and technology companies) as natural innovation arenas to develop ideas in living labs settings (Juujärvi \& Pesso, 2013). In comparison with a generic living lab, which focuses on facilitating interaction between end users and private actors, urban living labs are more oriented toward "urban" or "civic" innovation (Baccarne, Schuurman, Mechant, \& De Marez, 2014). Baccarne and colleagues (2014) also highlight that urban living labs are often supervised by (or have a close relation with) the local government and have a strong focus on social value creation and civic engagement and on non-commercial activities.

However, the distinction between the terms "living lab" and "urban living lab" is not clear in the literature (Steen \& van Bueren, 2017). For instance, Schliwa (2013) states that "sustainable living labs" targeting generation of knowledge within a small-scale real-life laboratory are similar to urban living labs but with a focus on the implementation of socio-technical innovations on a larger urban territory targeting knowledge generation as well as application. Thus, the urban living lab concept expands its activities on a broader urban territory, which also affects the way that key stakeholders are engaged (Schliwa, 2013). Also, an urban living lab has a distinct focus on knowledge and learning as a mean through which such interventions can be successfully achieved (Bulkeley et al., 2017).

Looking at the definition of an urban living lab, Steen and van Bueren (2017) state that researchers often adopt existing definitions related to the concept of "living lab", such as the one used by the European Network of Living Labs (ENoLL, 2016): "Living labs are defined as user-centered, open innovation ecosystems based on systematic user co-creation approach, integrating research and innovation processes in real life communities and settings" (Steen \& Van Bueren, 2017). But, Steen and van Bueren (2017) highlight that the term "urban living lab" often refers to a variety of local experimental projects of a participatory nature, meaning it is often used interchangeably with the terms "testing ground", "hatchery", "incubator", "maker space", "testbed", "hub", "city laboratory", "urban lab", or "field lab".

With the goal of operationalizing the definition of urban living labs, Steen and van Bueren (2017) assessed 90 sustainable urban innovation projects in the city of Amsterdam. Based on their research, they identified four key characteristics of an urban living lab, namely: aim, activities, participants, and context. Their analysis was based on sustainable urban innovation projects in general, not urban living labs in particular. Hence, Steen and Bueren (2017) highlight that their assessment shows that the majority of the projects, as living labs, did not include one or more of the defining elements of a living lab. They also argued that excluding one or some of these basic components of the living labs might lead to disappointing performance in the whole innovation development process. According to their study, the aims of urban living labs are innovation and formal learning. The main activities are innovation development, co-creation, and iteration of the design and development process by considering feedback from the previous steps. When it comes to participants, public and private sectors, citizens, and knowledge, institutions are of vital importance as is context, which is always a real-life everyday use context. With respect to the characteristics of an urban living lab, Voytenko and colleagues (2016) presented five of them: 1) geographical embeddedness, 2) experimentation and learning, 3) participation and user involvement, 4) leadership and ownership, and 5) evaluation and refinement.

Further, Juujärvi and Pesso (2013) have identified three main levels of engagement in the process of urban living labs. In the first type, the urban context can act as a technology-assisted research environment by collecting as much citizen feedback as possible by using different sensors and Internet of Things (IoT) deployments. In the second type, citizens can also be co-creators who contribute to designing and developing local services and urban artefacts (e.g., communal yards, day-care services). The third type of urban living lab represents a new kind of urban planning that uses novel processes and tools that are developed by actively engaging citizens. In this third type, the objective is to plan procedures and facilitate vision planning, which will lead to increased mutual learning of various stakeholders, including citizens.

Veeckman and van der Graaf (2015) identified three main benefits of viewing the city as an urban living lab: 1) it facilitates citizen participation and collaboration; 2) it facilitates co-creation processes in the city, and 3) it empowers citizens. They also suggested that, by using different tools and techniques, citizens who do not have very high technical skills are also able to participate in the progress of their cities and can contribute to the development of different solutions that are beneficial for their city as well as their everyday urban lives. 


\section{Urban Living Labs: Towards an Integrated Understanding of their Key Components}

Diana Chronéer, Anna Ståhlbröst, and Abdolrasoul Habibipour

Steen and van Bueren (2017) identified five main innovation-related activities in urban living labs: 1) research, 2) development, 3) testing, 4) implementation, and 5) commercialization. They then classified 90 potential living lab projects in the Amsterdam region under these five themes. Their findings showed that development of an innovation is the most frequent innovation process phase in an urban living lab. Steen and van Bueren also argued that only projects that conduct development activities can be considered as a living lab project. Accordingly, in an urban living lab context, the innovation must be developed in the city by including relevant stakeholders and citizens and testing or implementing an innovation would be a complementary phase.

In another study based in the Netherlands, designed to assess the role of urban experiments for local planning processes, Scholl and Kemp (2016) conducted a casebased analysis of the city of Maastricht and identified five key characteristics of urban living labs (which they labelled as "city labs") as a distinct analytical category for looking at urban labs and urban experiments from a planning perspective. First, city labs are hybrid organizational forms purposefully positioned at the border of local administration and society. Second, city labs are places of experimental learning and are learning environments for new forms of governance. Third, city labs are multi-stakeholder settings including the local administration and focus on co-creation. Fourth, city labs use co-creation in conducting experiments. And fifth, city labs approach complex problems in a multi-disciplinary way, by drawing on knowledge from different disciplines.

Different researchers have explored, defined, and characterized urban living labs, as summarized in Table 1. All of these studies have tried to clarify the concept by understanding urban living labs from different perspectives and at different levels. In these perspectives, there is a mixture of components (e.g., activities, participants, and hybrid organization form), activities (e.g., research, development, testing, evaluation), aims (e.g., innovation, learning, empowerment of citizens), principles (e.g., co-creation, multi-stakeholder engagement, participation) and contextual factors (e.g., geographical embeddedness, technology-assisted environment, learning environment) that constitute an urban living lab, which also contribute to the concept's complexity. Accordingly, we argue that a concise definition of the key components of an urban living lab is still lacking.

Therefore, in order to better understand the key components of an urban living lab, we will discuss the five key components of generic living labs (i.e., ICT and infrastructure, management structure, partners and users, research, and approach) as outlined by Bergvall-Kåreborn and colleagues (2009) and Ståhlbröst (2008) in the light of the key components of an urban living lab by analyzing other aspects that constitute its main components.

\section{Research Methodology}

Given the need for research into the components of urban living labs, this study uses a qualitative and exploratory research approach. To reach strong results in qualitative research, it is important to stimulate interaction between research and practice and to include a variety of perspectives in the study (Kaplan \& Maxwell, 2005). In this study, we were particularly interested in grasping the city representatives' understanding of an urban living lab and how they could work with a suitable framework in order to meet the cities' individual urban challenges.

\section{The UNaLab project}

This study was performed as part of the UNaLab project (730052-2), which is funded by the European Union under the Horizon 2020 research and innovation program. The UNaLab project aims to develop smarter, more inclusive, more resilient, and increasingly more sustainable societies through innovative nature-based solutions. The UNaLab partners (including 10 municipalities and members from research, business, and industry) commit to address the challenges that cities around the world are facing today, by focusing on climate and water-related issues, within an innovative and citizen-driven paradigm. UNaLab has three front-runner cities, Eindhoven, Genova, and Tampere, each with a track record of employing smart, citizen-driven solutions for sustainable development. These three front-runner cities will implement urban living lab demonstration areas within their cities. They will address identified challenges related to urban climate and water by co-creating nature-based solutions with local stakeholders and citizens using an innovative and systemic decision-support tool. The solutions then will be replicated in seven follower cities: Stavanger, Prague, Castellon, Cannes, Basaksehir, Hong Kong, and Buenos Aires plus they share experiences with observers such as the City of Guangzhou and the Brazilian Network of Smart Cities. The follower cities will therefore work in collaboration with the front-runner cities to develop nature-based solutions in a co-creation approach. In this study, we have mainly included the cities Eindhoven, Genova, Tampere, Stavanger, Prague, Castellon, Cannes, and Basaksehir because their representatives participated in the workshops. 


\section{Urban Living Labs: Towards an Integrated Understanding of their Key Components}

Diana Chronéer, Anna Ståhlbröst, and Abdolrasoul Habibipour

Table 1. Different perspectives to define an urban living lab

\begin{tabular}{|c|c|c|}
\hline & Key Features of an Urban Living Lab & Key Identifiers \\
\hline $\begin{array}{l}\text { Types } \\
\text { (Juujärvi \& Pesso, 2013) }\end{array}$ & $\begin{array}{l}\text { - A technology-assisted research environment } \\
\text { - Co-creating with citizens } \\
\text { - Actively engaging citizens in urban planning processes }\end{array}$ & $\begin{array}{ll}\text { - } & \text { Milieu } \\
\text { - } & \text { Activities }\end{array}$ \\
\hline $\begin{array}{l}\text { Benefits } \\
\text { (Veeckman \& van der } \\
\text { Graaf, 2015) }\end{array}$ & $\begin{array}{l}\text { - Facilitating citizen participation } \\
\text { - Facilitating co-creation processes } \\
\text { - Empowering citizens }\end{array}$ & $\begin{array}{l}\text { - Approach } \\
\text { - Principles }\end{array}$ \\
\hline $\begin{array}{l}\text { Characteristics } \\
\text { (Voytenko et al., 2016) }\end{array}$ & $\begin{array}{l}\text { - } \text { Geographical embeddedness } \\
\text { - Experimentation and learning } \\
\text { - } \text { Participation and user involvement } \\
\text { - Evaluation and refinement } \\
\text { - Leadership and ownership }\end{array}$ & $\begin{array}{l}\text { - } \text { Actions } \\
\text { - Components } \\
\text { - Contextual }\end{array}$ \\
\hline $\begin{array}{l}\text { Characteristics } \\
\text { (Scholl \& Kemp, 2016) }\end{array}$ & $\begin{array}{l}\text { - Hybrid organizational forms } \\
\text { - Learning environments } \\
\text { - Multi-stakeholder settings } \\
\text { - Co-creative experimentation } \\
\text { - Multi-disciplinary approach }\end{array}$ & $\begin{array}{l}\text { - } \text { Components } \\
\text { - Approach } \\
\text { - Contextual }\end{array}$ \\
\hline $\begin{array}{l}\text { Activities } \\
\text { (Steen \& van Bueren, 2017) }\end{array}$ & $\begin{array}{l}\text { - Research } \\
\text { - Development } \\
\text { - Testing } \\
\text { - Implementation } \\
\text { - Commercialization }\end{array}$ & - Activities \\
\hline $\begin{array}{l}\text { Characteristics } \\
\text { (Steen \& van Bueren, 2017) }\end{array}$ & $\begin{array}{l}\text { - Aim: innovation and learning } \\
\text { - Activities: co-creation and decision power, and feedback and iteration } \\
\text { - Participants: public, private, users, knowledge institutions } \\
\text { - Context: real-life use context }\end{array}$ & $\begin{array}{l}\text { - } \text { Activities } \\
\text { - } \text { Components } \\
\text { - } \text { Contextual }\end{array}$ \\
\hline
\end{tabular}

The UNaLab project aims to fulfil the present need to develop a framework that can support the development of an urban living lab from a different perspective and to identify and understand the key components, objectives, challenges, and characteristics of an urban living lab based on both theory and practice.

\section{Data collection methods}

In order to obtain a better understanding of urban living labs from the perspective of city representatives and to define the concept of an urban living lab, two work- shops were organized in the UNaLab project, followed by an open-ended questionnaire to validate the collected data in the two workshops.

The first workshop was held in November 2017 in the front-runner city of Genova, Italy, with seven UNaLab project partners to deepen the participant's knowledge and understanding of the urban living lab concept, while at the same time gathering information on the topic and capture their perspective as the city representative by reflecting on: 1) the key components of a 


\section{Urban Living Labs: Towards an Integrated Understanding of their Key Components}

Diana Chronéer, Anna Ståhlbröst, and Abdolrasoul Habibipour

traditional living lab as outlined by Bergvall-Kåreborn and colleagues (2009) and Ståhlbröst (2008), and 2) additional components derived from the urban living lab literature: innovation, an urban context, citizens, methodologies, and the management structure. Following this approach enabled us to refine the initial list of key components and add or remove other key components that are applicable in urban living lab context. The workshop participants were asked to respond to questions such as: From your perspective, what should urban living labs achieve at the end? What is the problem or challenge they aim to solve? What is an urban context to experiment in? What is the innovation in your context? Who should be engaged in the innovation process and how? What is the management structure for the governance of an urban living lab? The first workshop involved 35 participants with representatives from both front-runner and follower cities and lasted for approximately 60 minutes. In this first workshop, general discussion around the tables was captured on post-it notes posted on the templates. At the end of the workshop, the main outcomes per each table were shared in a short debriefing by the participants.

The aim of the second workshop, carried out in November 2018 in the follower city of Basaksehir, Turkey, was to validate the results obtained in the previous workshop, as well as to exchange knowledge on urban living labs and to gain a rich picture of the current situation of the cities by reflecting on the refined key components of an urban living lab. In this workshop, we were also interested in knowing in what phase of lab development the cities were in and how to proceed with setting up and running a living lab in their own cities. Seven participants from both front-runners as well as follower cities attended the workshop and it lasted approximately 80 minutes. In this workshop, general discussions around three tables was captured on templates aiming to support the set-up of an urban living lab. At the end of the workshop, a feedback form was distributed to the participants, who reflected on the main learning outcome of the session as well as the next step of developing the urban living lab framework from their perspective.

When analyzing the results from the second workshop, confusion about the concept of urban living labs appeared, hence, an open-ended questionnaire was distributed (in December 2018) to the front-runner and following cities with the aim of gaining more insights into how the concept of the urban living lab was understood and implemented (or planned to be implemented) in the front-runner cities.
To promote stronger and more reliable results, the collected data was independently analyzed by three researchers.

\section{Results}

\section{The first workshop: Genova, Italy}

In the first workshop, seven templates were distributed between participants to discuss the initially identified key components of an urban living lab. The three templates focused on: 1) the definition and objectives of an urban living lab in general; 2) the five traditional key components of a living lab, and some additional components extracted from the literature: innovation, an urban context, citizens, methodologies, and the management structure; and 3) the reflections about the templates. In total, the main challenges with the innovative nature-based solutions were identified as involving stakeholders, increasing trust, and co-creating with the citizens.

Regarding the city stakeholders, their representatives in the workshop highlighted the importance of identifying and engaging multiple citizen groups ranging from children to the elderly, and incorporating diverse groups such as business owners, public servants, researchers, visitors to the "space", and people with disabilities.

Looking at the cities' individual urban challenges (i.e., what the cities want to accomplish), they all highlight environmental issues - on a global level as well as on a more common and local level. On a global level, climate change and developing an ecosystem were highlighted. On a more common, city level, the focus was on bringing the nature back into the city. Finally, on a more specific local level, the focus was on decreasing local climate problems, such as flooding. This finding is in accordance with what was stated in earlier research that urban living labs are more oriented on "urban" or "civic" innovation (Baccarne, Schuurman, Mechant, \& De Marez, 2014).

The potential objectives of urban living labs discussed by the city representatives were in several cases similar to the generic living lab concept (Bergvall-Kåreborn et al., 2009; Ståhlbröst, 2008), such as providing a framework for research work or for innovating, experimenting, knowledge transfer, and co-creation. However, some more urban-related aspects highlighted in the definitions were the environment where citizens participate in designing solutions, the way to co-construct the city with citizens and local authorities, a place to involve citizens to experiment ideas at, a shared long- 


\section{Urban Living Labs: Towards an Integrated Understanding of their Key Components}

Diana Chronéer, Anna Ståhlbröst, and Abdolrasoul Habibipour

term program of activities, getting people involved in creating their future, a real life innovation and experience, and focusing on the long-term scaling of an innovation.

In addition, some city representatives highlighted other specific urban-related aspects in the cities such as: covering the full spectrum of challenges facing the city; solving urban problems in an effective and sustainable way by adopting user-centred design; adding visibility to nature-based solutions; improving the livability, sustainability, and social-hydrological resilience of the urban area; including citizens in decision making regarding issues related to their living environment; raising awareness of the citizens; and creating a strong ecosystem and joint value system model.

The most difficult components to discuss in the workshop were the potential management structure for governance of an urban living lab and its long-term financing. Almost all groups identified these as the most difficult questions to answer. Here, the city representatives discussed issues such as how to finance an urban living lab and a nature-based solution on a longterm basis, who should be responsible for it, how should an urban living lab be managed and by whom, and whether an urban living lab should be implemented in the whole city and all its development activities as part of a citizen-engagement policy. Based on that the discussions, we conclude that the concept of the urban living lab is complex because it is implemented in a city context. Other aspects mentioned by the workshop participants when they were asked to explain and elaborate on the key defining components of an urban living lab included testing new solutions, a way to coconstruct the city with citizens and local authorities, an innovative governance experience in a real urban context, and a place for implementing new networks.

\section{The second workshop: Basaksehir, Turkey}

With the aim to validate the results obtained in the previous workshop and refine the core components of an urban living lab, seven templates were developed. The templates were mainly based on the previous workshop and literature related to the concept of the urban living lab, however, ICT and infrastructure and key stakeholders were also added to the previous templates based on the feedback from the previous phase.

The outcome of the second workshop resulted in a knowledge exchange between participants to obtain a rich picture of the current situation of the cities and re- flecting on the key components of an urban living lab. The workshop also enabled the cities to develop their understanding of what phase of development they were in and how to proceed with setting up and running their own urban living lab. The workshop participants learnt about urban living labs through the introduction presentation as well as through their discussions into the seven key components of the urban living lab framework (i.e., the definition and objectives of an urban living lab, the innovation, the context, partners and users, approach and methodology, the management structure, and finally ICT and infrastructure).

In this second workshop, the workshop participants identified the following three templates as most challenging: 1) innovation (which is the nature-based solution in their context), 2) the ICT and infrastructure, and 3) the approach and methodology. Furthermore, some participants argued that some questions in the templates did not apply to their situation, which confirmed the lack of clarity and complex nature of the urban living lab concept. This was the feedback that we were aiming for, so that we could develop templates that will be helpful for cities when setting up their urban living labs.

At a glance, the results of the workshop showed that, in relation to the nature-based solutions (i.e., the innovation in urban living labs), some practical aspects are influential in the process of solution development. The participants highlighted a need to ask questions such as: How long does the development and experimentation of the nature-based solution take? How much does it cost? What kind of human resources are needed? Also, regarding the partners and users, the cities sought more help and support to understand what stakeholders should be involved in the process of developing nature-based solutions and in which phase. And, related to the citizens, it was suggested that the way in which citizens are affected by the nature-based solution should be taken into account in the templates, not only during the solution development and implementation process, but also after it has been completed. In respect to the ICT and infrastructure, the participants prioritized questions related to how the data, hardware, software, and networks can be put to work. Moreover, they felt that it was important to identify who is responsible for each of the components of infrastructure. As suggested by the city representatives, a clear distinction must be made between open and closed data and the way that it should be managed within an urban living lab. 


\section{Urban Living Labs: Towards an Integrated Understanding of their Key Components}

Diana Chronéer, Anna Ståhlbröst, and Abdolrasoul Habibipour

\section{The questionnaire}

After the second workshop, we sent an open-ended questionnaire to the city representatives and received nine responses: five from front-runner cities and four from follower cities.

When asked the question of "What is your view is an urban living lab?", the results showed that different cities have interpreted the concept of an urban living lab differently. Some of them have viewed the urban living lab as an approach to manage the process of developing nature-based solutions, some city representatives saw it as a test bed to experiment with the nature-based solutions, some considered it as a physical environment (e.g., a park, a housing block, or a district, or even a whole city) and some understood it as a tool that can foster the innovation and co-creation process in the city context by involving citizens and other relevant stakeholders. However, the responses also showed that some representatives were not very familiar with the concept of the urban living lab. For example, a representative from one follower city stated: "I don't have much experience in this field. I've listened in many places about the concept of the urban living lab, but my definition is an urban space for citizens to test innovation."

According to our experience and previous discussions with the city representatives, many of them could not make a clear distinction between an urban living lab and a nature-based solution at the conceptual level. For some cities, urban living labs are not necessarily for the implementation and construction of nature-based solutions; however, they consider the approach (or tool) useful to design, develop, implement, and test various types of innovation, including nature-based solutions. The responses to this question also showed that sometimes they consider urban living lab as a solution to develop a highly complex technological innovation, which might not be a solution to address challenges such as climatic and environmental challenges.

In this questionnaire, we also asked in what phase of development of a nature-based solution the front-runner and follower cities are and where do they see themselves in the process of setting up and running their own urban living lab. In so doing, the cities were asked to respond to the question of "From your perspective, have you implemented an urban living lab in your city?" The answers ranged widely: one said their urban living lab was fully implemented, two said their implementation was nearly done, one said they were plan- ning one but had not started, one said they will not implement one, and another said they did not know. The representative who stated that their urban living lab has been fully implemented also mentioned that "it is not implemented for nature-based solutions or as part of the UNaLab. The municipality has several urban living lab initiatives regarding social issues in specific city districts. The urban living labs are financed by the municipality and also partly by the government to improve living conditions. The municipality is responsible for the urban living labs. A range of activities are used for citizen involvement: meetings, workshops, and office days for the municipal workers in the field."

One of the cities that believed they have almost implemented an urban living lab said: "The city has opened this planning phase area for $R \& D$ projects, experiments, people, and culture". From their perspective, systematic methods to run an urban living lab (e.g., vision, data management, and learning) are developed. However, they emphasized that the next steps (experimentation) are currently under ideation and planning. As another city mentioned: "Some urban living labs are already working - on other subjects. For nature-based solutions, we have existing projects in the inner city where we implement nature-based solutions. The learning part is what we want to improve. This needs more focus and organization. Finance and co-creation or other engagement of stakeholders is part of the existing project."

One of the front-runner cities that reported planning to start setting up and running their urban living lab stated that, from their perspective, an urban living lab needs a physical place to be operationalized: "The administration is thinking of finding a physical place to install the urban living lab, but it has not yet been decided how to implement it. It will probably be managed by the municipality."

One city has also emphasized that they are not going to set up an urban living lab. In response to the question of "What is the main reason why you will not implement an urban living lab?", they mentioned that they do not have enough power and influence to implement an urban living lab in their city. As they said: "We are the body in charge of developing the concept behind the city's architecture, urbanism, development, and formation. We mainly draft and coordinate documents in the following areas: strategic and spatial planning and development, public space, transport, technical matters, and landscape such as economic infrastruc- 


\section{Urban Living Labs: Towards an Integrated Understanding of their Key Components}

Diana Chronéer, Anna Ståhlbröst, and Abdolrasoul Habibipour

ture - and we can't implement projects". However, they have considered an urban living as a positive approach for the future.

In the last question, we asked them to share any other feedback or insights that may be relevant to the main aim of the questionnaire. In general, most of them found that the concept of the urban living lab was very interesting concept, and they were interested in knowing more about it. Some city representatives asked for more concrete examples, step-by-step guidelines, and precise instructions in order to gain knowledge on how to set up and run an urban living lab in their cities. They were also seeking training sessions from living lab experts who would be able to exchange knowledge in this field.

\section{Discussion}

Through this study, we identified seven key components of an urban living lab. These components are derived from the literature and modified according to perspective of city representative in the study. The following components are highlighted:

1. Governance models including management structure, politics, and policies

\section{Financing and business models}

3. A physical representation that takes place in a reallife setting in the city context

4. An innovation to experiment with (in this article, usually a nature-based solution).

5. Partners and end users, including citizens, public and private actors, and academic institutions (i.e., a quadruple helix)

6. Approaches for engaging different stakeholders and collecting data

7. ICT and infrastructure such as IoT devices, sensors, and tools

Figure 1 illustrates these seven key components of an urban living lab in contrast to the five key components of a traditional living lab. In an urban living lab, less emphasis is placed on the component of research, probably due to the fact that the urban living lab activities are carried out in a city context with the aim to create better living conditions for its citizens. However, it has been emphasized that learning and knowledge sharing is a vital part of an urban living lab (Steen \& van Bueren, 2017), which might imply that research could be an important component of an urban living lab, even though our study does not reflect this as clearly.

The first component of management, in a previous study (Ståhlbröst, 2008), focused on how the living lab should be managed in order to become sustainable. In the urban living lab, this component has been enriched with the aspect of governance and also politics. The result indicates that urban living lab activities must be supported by decision makers in the cities and also by politicians if they are to happen, hence, an urban living lab has a more political dimension to it than traditional living labs. The need for leadership, ownership, and management of the urban living lab has been discussed in both Juujärvi and Lund (2016) and Voytenko and coauthors (2016), who also stress the balancing act needed between steering and controlling and the urban living lab's need to be flexible and effective. These authors do not discuss the area of politics and policy making and its relevance for urban living labs and their success. For an urban living lab to be sustainable on a long-term basis, policies supporting the approach need to be implemented. One such policy could be, for instance, that all urban development projects in a city

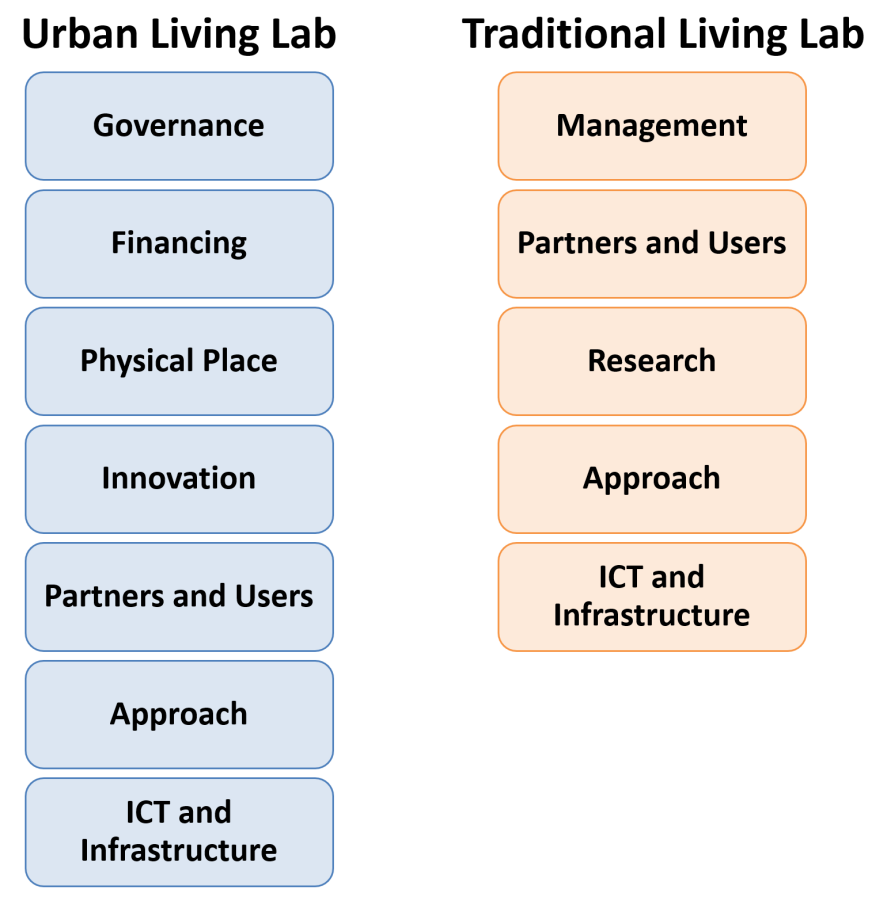

Figure 1. The key components of an urban living lab vs. a traditional living lab 


\section{Urban Living Labs: Towards an Integrated Understanding of their Key Components}

Diana Chronéer, Anna Ståhlbröst, and Abdolrasoul Habibipour

should be co-created with citizens. For this to happen, policies, governance models, and allocation of resources are of vital importance. Hence, our findings can be related to the argument by Baccarne, Schuurman, Mechant, and De Marez (2014), which states that local governments and decision makers have a strong influence. However, although they focus on social value creation and citizen engagement on non-commercial activities -those are expected outcomes of the urban living lab activities - we claim that decision makers have a prominent role in the existence of urban living labs.

This leads to the second component that differs from what previous research has identified: the financing and business model component. This can be seen as being part of the governance and management component, but based on our study, we see that financing the urban living lab and its activities is crucial to make it happen and thus it is key to its sustainability. This component has not been discussed in previous research, which can be explained by the focus on urban living labs as innovation projects (e.g., Juujärvi \& Lund, 2016; Steen \& van Bueren, 2017; Voytenko et al., 2016), where the financing of the project is pre-determined. In our study, the city representatives view an urban living lab as a "long-term program", an environment, and as a place. Hence, it emerges as something that needs a long-term commitment from the city, and thus there is a need to have both a financing model and well as a maintenance plan. The city representatives in this study did not highlight the business model concept as such but mentioned that finding financing, ways to engage citizens and other stakeholders, and building relationships with them, are all part of a business model and hence are needed in making an urban living lab sustainable.

One precondition in living lab activities is that they are situated in real-world contexts, not constructed laboratory settings. Thus, inherent in the concept of urban living labs is the component of physical context, or geographical embeddedness, as Voytenko colleagues (2016) refer to. This means that an urban living lab needs to have some kind of physical representation (Steen \& Bueren, 2017), which is in contrast to traditional living labs, which tend to be more mobile and dynamic. This place can either be where the innovation is implemented, in this article the location of the naturebased solution, or a place where stakeholders can be invited to participate in co-creation activities, that is an urban living lab "office". The physical representation is also connected to the components of financing and governance: a physical implementation needs to be maintained over a certain period of time to create value for the citizens. Here, the physical context can be assisted by technology, as suggested by Juujärvi and Pesso (2013), but it can also be a physical representation of the urban living lab activities as in the UNaLab project with its nature-based solutions. The urban living labs in our study were bounded to a place in which experimentation and co-construction takes place. These places also need to alter their character to create an experience of nature and enhanced feeling that increases a citizen's awareness of nature and sustainability. In traditional living lab settings, innovation is not regarded as a component as such since the living lab is viewed as a milieu for innovation, in other words, the goal is to support innovation activities and engage different stakeholders in an innovation process. But in an urban context, the component of innovation can be regarded as a desired outcome from the urban living lab activities, but also as an important component of the urban living lab itself. After all, without an innovation to experiment with, co-create, or test, there would be no urban living lab activities. The innovation does not need to be decided on before the activities begin; identifying the innovation could be within the scope of citizen participation activities. Related to this component, it is important to identify what the aim of the innovation is and what value it aims to create for whom.

In respect to the component of partners and users, the specific relationship between partners and users is emphasized in the traditional living lab literature. In an urban context, a mixture of different stakeholders is highlighted: public and private sectors, research institutes, and citizens should all be engaged in urban living lab processes, meaning the lab is a multi-stakeholder setting (Schnoll \& Kemp, 2016). Also, the characteristics of the citizens and their role are somewhat different in urban living labs than in traditional living labs. This means that, in an urban living lab, the citizens are involved as citizens, and not necessarily as users, given that there might not be a solution to "use" but only to experience or being affected by once the solution is in place. For instance, a nature-based solution that prevents a city from flooding has no obvious users, but is has "affectees" that no longer have a flooded city and thus their experience is affected positively. By being engaged in the co-construction of these nature-based solutions in urban areas, citizens also gain the opportunity to become actively engaged, to learn, and to thus feel responsible and also empowered to take action against situations that might have an impact on them. 


\section{Urban Living Labs: Towards an Integrated Understanding of their Key Components}

Diana Chronéer, Anna Ståhlbröst, and Abdolrasoul Habibipour

Hence, looking at the partners and users component, it includes the inherent characteristic of participation and inclusion, which can lead to empowered, enlightened, and active citizens that collaboratively wants to contribute to the sustainability of the city. Involving citizens in an urban living lab also means that the focus might shift from co-creation to co-constructing. This means that, in the cities we have studied, the focus is on constructing a nature-based solution in a specific place and thus creating an attractive space where citizens can enjoy the place. Hence, the co-construction of the place precedes the co-creation of the space.

Finally, the last components, the approach and the ICT and infrastructure, are similar in a traditional living lab and in an urban context. There is a need for a variety of methods and tools to support the urban living lab activities. Again, a multi-disciplinary approach is required (Scholl \& Kemp, 2016). In relation to the ICT and infrastructure, it is of importance to clarify the responsibility of each component of the infrastructure and the distinction of open data and closed, and the way it should be managed within an urban living lab.

\section{Conclusion}

As our results have illustrated, the urban living lab concept can be understood in many different ways: it can be seen as a tool, an approach to co-construct innovations, a platform, an environment to a test bed, a long-term program, or a development model. Understanding the components above provides the basis for setting up and managing an urban living lab, but merely having the components in place will not guarantee a viable and sustainable lab. It is also important to clearly define the objective of an urban living lab and design its inherent characteristics to increase its likelihood of success.

To conclude, the results of our study enabled us to provide a unified definition for an urban living lab that includes the city representative view:

"An urban living lab is a local place for innovative solutions that aims to solve urban challenges and contribute to long-term sustainability by actively and openly co-constructing solutions with citizens and other stakeholders."
Hence, the results also show that there are some differences between a traditional living lab and an urban living lab regarding some of the key components. An urban living has four specific dimensions. First, it is a long-term organization that support the process of enhancing sustainability in an urban area by having all the components organized in a viable manner. It is not merely a small innovation project carried out in a city context with citizens. Second, it is an approach through which citizens and other stakeholders should be engaged by using different methods with the objective to create value and long-term sustainability of the solution. Third, it is locally bounded to a place where local issues in the urban area can be experimented with while contributing to global challenges. Fourth, it is a political act to implement an urban living lab since the activities need to be supported by politicians and there is a need for policies to ensure sustainability. In summary, the importance of governance, ownership structure, and financing indicate that a more sustainable business model is needed for a living lab in an urban context.

This study contributes to the body of living lab literature by providing an integrated model as well as an empirically derived definition for an urban living lab in order to better understand its key components. This understanding can serve as a basis for the cities to know how to setup, govern, and manage their urban living labs and the factors influencing their innovations and development processes. The presented model will also help answer questions such as who should be engaged and how, what methods should be applied to engage citizens, who starts the process, who is responsible to run the experimentation process, and how the governance model of an urban living lab should be structured.

\section{Acknowledgements}

We would like to thank all the city representatives who contributed to this research. We also gratefully appreciate the reviewer feedback and the efforts of the Editorin-Chief, Chris McPhee, for his valuable comments, suggestions, and guidelines to improve this article. This work was funded by the European Commission in the context of the Horizon 2020 project UNaLab (Grant Agreement No. 730052), which is gratefully acknowledged. A portion of this work was presented at the ISPIM 2018 conference in Stockholm, Sweden. 


\section{Urban Living Labs: Towards an Integrated Understanding of their Key Components}

Diana Chronéer, Anna Ståhlbröst, and Abdolrasoul Habibipour

\section{About the Authors}

Diana Chronéer is an Associate Professor in the Information Systems department at Luleå University of Technology in Sweden. She teaches organizational development through IT and sustainable business models from a digital perspective. Her main research interests are in the areas of digital service innovation, business model development, information logistics, and project management.

Anna Ståhlbröst is the Chair Professor in Information Systems at Luleå University of Technology, Sweden. Her research interests focus on the possibilities and challenges with the ongoing digital transformation for people, organizations, and society. In particular, she is interested in the citizen perspective when digital service innovations are developed within the context of urban living labs for smart cities and regions. Her research is related to different application areas such as smart cities and regions, crowdsourcing, everyday use, and online privacy. Her research has been published in several international journals, conference proceedings, and books.

Abdolrasoul Habibipour is a PhD student in Information Systems at Luleå University of Technology in Sweden and is a User Engagement Expert at Botnia Living Lab, Sweden. His research focuses on user engagement in living lab context, with a particular emphasis on users' motivations and needs. Abdolrasoul has experience teaching and supervising students at the undergraduate and postgraduate level and also serves as a reviewer in various international conferences and scientific journals. He has been involved in international innovation and research projects such as Privacy Flag and USEMP projects and is currently working in UNaLab and U4IoT projects, all of which are financed by the European Commission.

\section{References}

Almirall, E., Lee, M., \& Majchrzak, A. 2014. Open Innovation Requires Integrated Competition-Community Ecosystems: Lessons Learned from Civic Open Innovation. Business Horizons, 57(3): 391-400. https://doi.org/10.1016/j.bushor.2013.12.009

Almirall, E., Lee, M., \& Wareham, J. 2012. Mapping Living Labs in the Landscape of Innovation Methodologies. Technology Innovation Management Review, 2(9): 12-18.

http://doi.org/10.22215/timreview/603

Baccarne, B., Mechant, P., Schuurman, D., Colpaert, P., \& De Marez, L. 2014. Urban Socio-Technical Innovations with and by Citizens. Interdisciplinary Studies Journal, 3(4): 143-156.

Baccarne, B., Schuurman, D., Mechant, P., \& De Marez, L. 2014. The Role of Urban Living Labs in a Smart City. In Proceedings of the XXV ISPIM Innovation Conference, June 8-11, 2014, Dublin, Ireland.

Ballon, P., \& Schuurman, D. 2015. Living Labs: Concepts, Tools and Cases. info, 17(4).

https://doi.org/10.1108/info-04-2015-0024

Bergvall-Kåreborn, B., Ihlström Eriksson, C., Ståhlbröst, A., \& Svensson, J. 2009. A Milieu for Innovation: Defining Living Labs. In K. R. E. Huizingh, S. Conn, M. Torkkeli, \& I. Bitran (Eds.), Proceedings of the 2nd ISPIM Innovation Symposium: Simulating Recovery - The Role of Innovation Management, December 6-9, 2009, New York, USA.

Bulkeley, H., Coenen, L., Frantzeskaki, N., Hartmann, C., Kronsell, A., Mai, L., Marvin, S., McCormick, K., van Steenbergen, F., \& Voytenko Palgan, Y. 2016. Urban Living Labs: Governing Urban Sustainability Transitions. Current Opinion in Environmental Sustainability, 22: 13-17.

https://doi.org/10.1016/j.cosust.2017.02.003

Chesbrough, H. 2003. Open Innovation. Boston: Harvard Business School Press.

ENoLL. 2006. What is a Living Lab? European Network of Living Labs (ENoLL). Accessed August 2, 2016:

http://www.openlivinglabs.eu/

Evans, J., \& Karvonen, A. 2011. Living Laboratories for Sustainability: Exploring the Politics and Epistemology of Urban Transition. In $\mathrm{H}$. Bulkeley, V. Castán Broto, M. Hodson, \& S. Marvin (Eds.), Cities and Low Carbon Transitions: 126-141. London: Routledge.

Frantzeskaki, N., Borgström, S., Gorissen, L., Egermann, M., \& Ehnert, F. 2017. Nature-Based Solutions Accelerating Urban Sustainability Transitions in Cities: Lessons from Dresden, Genk and Stockholm Cities. In N. Kabisch, H. Korn, J. Stadler, \& A. Bonn (Eds.), NatureBased Solutions to Climate Change Adaptation in Urban Areas: 65-88. Cham, Switzerland: Springer. https://doi.org/10.1007/978-3-319-56091-5_5

Franz, Y., Tausz, K., \& Thiel, S.-K. 2015. Contextuality and CoCreation Matter: A Qualitative Case Study Comparison of Living Lab Concepts in Urban Research. Technology Innovation Management Review, 5(12): 48-55. http://doi.org/10.22215/timreview/952

Juujärvi, S., \& Lund, V. 2016. Enhancing Early Innovation in an Urban Living Lab: Lessons from Espoo, Finland. Technology Innovation Management Review, 6(1): 17-26. http://doi.org/10.22215/timreview/957 


\section{Urban Living Labs: Towards an Integrated Understanding of their Key Components Diana Chronéer, Anna Ståhlbröst, and Abdolrasoul Habibipour}

Juujärvi, S., \& Pesso, K. 2013. Actor Roles in an Urban Living Lab: What Can We Learn from Suurpelto, Finland? Technology Innovation Management Review, 3(11): 22-27. http://doi.org/10.22215/timreview/742

Kaplan, B., \& Maxwell, J. A. 2005. Qualitative Research Methods for Evaluating Computer Information Systems. In J. G. Anderson \& C. E. Aydin (Eds), Evaluating the Organizational Impact of Healthcare Information Systems: 30-55. New York: Springer. https://doi.org/10.1007/0-387-30329-4_2

Schaffers, H., \& Turkama, P. 2012. Living Labs for Cross-Border Systemic Innovation. Technology Innovation Management Review, 2(9): 25-30.

http://doi.org/10.22215/timreview/605

Schliwa, G. 2013. Exploring Living Labs through Transition Management - Challenges and Opportunities for Sustainable Urban Transitions. Master's thesis. Lund, Sweden: The International Institute for Industrial Environmental Economics. http://lup.lub.lu.se/student-papers/record/4091934

Scholl, C., \& Kemp, R. 2016. City Labs as Vehicles for Innovation in Urban Planning Processes. Urban Planning, 1(4): 89-102. https://doi.org/10.17645/up.v1i4.749

Schuurman, D. 2015. Bridging the Gap between Open and User Innovation? Exploring the Value of Living Labs as a Means to Structure User Contribution and Manage Distributed Innovation. Doctoral dissertation. Ghent, Belgium: Ghent University.

Ståhlbröst, A. 2008. Forming Future IT - The Living Lab Way of User Involvement. Doctoral dissertation. Luleå, Sweden: Luleå University of Technology.

Steen, K., \& Bueren, E. 2017. The Defining Characteristics of Urban Living Labs. Technology Innovation Management Review, 7(7): 21-33.

http://doi.org/10.22215/timreview/1088

Veeckman, C., \& van der Graaf, S. 2015. The City as Living Laboratory: Empowering Citizens with the Citadel Toolkit. Technology Innovation Management Review, 5(3): 6-17. http://doi.org/10.22215/timreview/877

Voytenko, Y., McCormick, K., Evans, J., \& Schliwa, G. 2016. Urban Living Labs for Sustainability and low Carbon Cities in Europe: Towards a Research Agenda. Journal of Cleaner Production, 123: $45-54$.

https://doi.org/10.1016/j.jclepro.2015.08.053
Citation: Chronéer, D., Ståhlbröst, A., \& Habibipour, A. 2019. Urban Living Labs: Towards an Integrated

(cc) BY

Understanding of their Key Components. Technology

Innovation Management Review, 9(3): 50-62.

http://doi.org/10.22215/timreview/1224

Keywords: urban living lab, ULL, living lab, key components, definition, nature-based solutions, NBS, UNaLab, innovation 


\section{Academic Affiliations and Funding Acknowledgements}
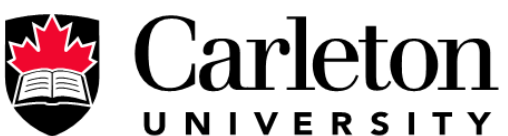

U N I V E R S I T Y

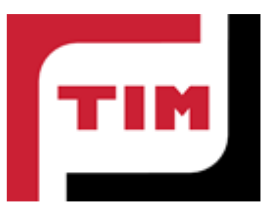

Technology Innovation Management (TIM; timprogram.ca) is an international master's level program at Carleton University in Ottawa, Canada. It leads to a Master of Applied Science (M.A.Sc.) degree, a Master of Engineering (M.Eng.) degree, or a Master of Entrepreneurship (M.Ent.) degree. The objective of this program is to train aspiring entrepreneurs on creating wealth at the early stages of company or opportunity lifecycles.

- The TIM Review is published in association with and receives partial funding from the TIM program. 